\title{
THE PATTERN OF CORTICAL INJURY IN THE RAT AND ITS RELATION TO MASS ACTION ${ }^{1}$
}

\author{
NORMAN R. F. MAIER \\ Department of Psychology, Tniversity of Michigan \\ TWO TEXT FIGLRES AND THREE PLATES
}

(Accepted for publication February 28, 1934)

\begin{tabular}{|c|c|}
\hline CONTENTS & \\
\hline Introduction $\ldots \ldots \ldots$ & \\
\hline Method and procedure $\ldots \ldots \ldots \ldots \ldots \ldots$ & \\
\hline A. The psychological function studied & \\
\hline B. Seoring of tests $\ldots \ldots \ldots \ldots \ldots$ & \\
\hline C. The subjects used $\ldots \ldots \ldots$. & \\
\hline D. The lesion patterns compared & \\
\hline E. Procedure $\ldots \ldots \ldots \ldots \ldots \ldots$ & \\
\hline 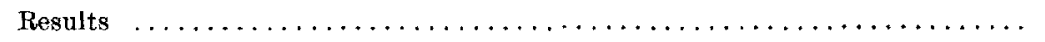 & \\
\hline $\begin{array}{c}\text { A. A comparison of the scores made by rats with different types of } \\
\text { lesions } \ldots \ldots \ldots \ldots \ldots \ldots \ldots \ldots \ldots \ldots \ldots \ldots \ldots \ldots \ldots \ldots \ldots \ldots \ldots \ldots \ldots\end{array}$ & \\
\hline B. The relation between size of lesion and scores made $\ldots \ldots \ldots \ldots \ldots$ & \\
\hline ect of total versus symmetrical destruction $\ldots \ldots \ldots \ldots \ldots$ & \\
\hline D. A comparison of the spacing of the lesions $\ldots \ldots \ldots \ldots \ldots \ldots$ & \\
\hline E. The effect of sub-cortical injuries on scores $\ldots \ldots \ldots \ldots \ldots \ldots$ & \\
\hline $\begin{array}{l}\text { F. The relation between the pattern of the lesion and post-operative } \\
\text { scores } \ldots \ldots \ldots \ldots \ldots \ldots \ldots \ldots \ldots \ldots \ldots \ldots \ldots \ldots \ldots \ldots\end{array}$ & \\
\hline $\operatorname{mmary} \ldots .$. & \\
\hline
\end{tabular}

\section{INTRODUCTION}

The concept of mass action as an alternative for specific localization has been experimentally tested in a large number of cases by numerous investigators and on a variety of psychological functions. The results of these experiments have recently been summarized by Lashley ('33). His summary is reproduced in table 1 . From this table it is obvious that the

- The Faculty Research Fund of the University of Michigan has given finaneial assistance in the publication of this paper.

$$
409
$$

THE JOURNAL OF COMPARATINE NEUROLOGY, YOI. 60, No. 3 
analogy of a telephone switch board is entirely inadequate for illustrating cortical function. The concept of mass action, on the other hand, is supported by the high correlation coeffieients which characterize the table. In the case of the acquisition of simple sensory habits, partially decorticated animals are as efficient as normal animals. Such evidence neither supports nor refutes mass action. That the retention of such habits depends upon the mass of certain large general areas indicates that both of the concepts must in some way be combined to form a new concept. In the more general and in the more complex functions, mass action is an adequate concept. Thus it is evident that in some functions mass action and its corollary, equipotentiality, are adequate concepts, whereas in other functions some form of functional differentiation must be incorporated in our theories. It may be that in still other functions some form of specific functional differentiation may become evident. In any case no particular part of the cerebral cortex is set aside for any one function and no other. Because of these complexities, it seems that the limitations of mass action must be examined in detail. Its importance as a concept cannot be denied, but its limitations must be known before it can be fully appreciated.

When we substitute the concept of mass action for the concept of specific localization in brain physiology we must, of necessity, modify our whole trend of thinking in problems related to cortical function. If we take mass action seriously, we must wonder just what is included in the term 'mass.' It is true that the extent of deterioration in the adaptive forms of behavior in animals is correlated with the mass of cortical tissue destroyed, no matter where destroyed, and that equal amounts of destruction tend to show equal amounts of loss, but it does not necessarily follow that this mass as such is the only determining factor. Mass, for example, may be one factor determining the intensity of an injury, but the distribution of this mass may be a contributing factor. If this is true, then concentrated masses should result in greater deterioration than distributed masses. 
TABLE i

(From Lashley, '33, pp. 28-29.)

The relation between extent of lesion and efficiency of performance in statistical studies of the effects of cerebral injury

\begin{tabular}{|c|c|c|c|}
\hline TASK & LOCUS OF LESION & $\begin{array}{l}\text { COEFWICLENT OF } \\
\text { CORRELATION }\end{array}$ & REFERENOE \\
\hline Postoperative retention of simple maze & Frontal areas & Zero & Lashley and Franz ('17) \\
\hline Learning double platform box & Frontal areas & $0.24 \pm 0.15$ & Lashley ('20) \\
\hline Ibid., corrected for motor disorders & & Zero & Lashley ('20) \\
\hline Initial learning, delayed alternation & Frontal areas & $-0.02 \pm 0.19$ & Loueks ('31) \\
\hline Ibid., postoperative relearning & Frontal areas & $0.54 \pm 0.12$ & Loucks ('31) \\
\hline $\begin{array}{l}\text { Postoperative maze learning, } 8 \text { culs de } \\
\text { sac }\end{array}$ & Frontal areas & $0.64 \pm 0.08$ & Maier ('32 a) \\
\hline Reasoning, postoperative records & Frontal areas & $0.54 \pm 0.09$ & Maicr ('32 a) \\
\hline $\begin{array}{l}\text { Light-darkness diserimination, post- } \\
\text { operative learning }\end{array}$ & Visual cortex & $0.08 \pm 0.14$ & Lashley ('26) \\
\hline Ibid., postoperative relearning & Visual cortex & $0.72 \pm 0.05$ & Lashley ('26) \\
\hline Ibid., corrected for critical area & Visual cortex & $0.73 \pm 0.08$ & Lashley ('32) \\
\hline Ibid., postoperative releaming & Visual cortex & $0.64 \pm 0.10$ & Lashley ('30 a) \\
\hline $\begin{array}{l}\text { Postoperative learning discrimination } \\
\text { two lights }\end{array}$ & Visual cortex & $0.58 \pm 0.10$ & Lashley ('30 a.) \\
\hline $\begin{array}{l}\text { Postoperative relearning discrimina- } \\
\text { tion two lights }\end{array}$ & Visual cortex & $0.65 \pm 0.10$ & Lashley ('30 a) \\
\hline $\begin{array}{l}\text { Difference threshold discrimination } \\
\text { two lights }\end{array}$ & Visual cortex & $0.49 \pm 0.09$ & Lashley ('30 a) \\
\hline Visual acuity and pattern vision & Visual ecrtex & $\begin{array}{l}\text { All-or-nothing } \\
\text { effect }\end{array}$ & Lashley ('31 e) \\
\hline $\begin{array}{l}\text { Reasoning, postoperative records } \\
\text { Postoperative retention reaction to }\end{array}$ & Visual cortex & $0.75 \pm 0.05$ & Maier ('32 b) \\
\hline noise & Auditory cortex & $0.61 \pm 0.11$ & Wiley ('32) \\
\hline $\begin{array}{l}\text { Postoperative maze learning, } 8 \text { culs } \\
\text { de sac }\end{array}$ & All parts & $0.86 \pm 0.03$ & Lashley ('29a) \\
\hline Ibid., 3 culs de sac & All parts & $0.65 \pm 0.07$ & Lashley ('29 a) \\
\hline Ibid., 1 cul de sac & All parts & $0.30 \pm 0.10$ & Lashley ('29 a) \\
\hline $\begin{array}{l}\text { Postoperative maze retention, } 8 \text { euls } \\
\text { de sac }\end{array}$ & All parts & $0.51 \pm 0.11$ & Lashley ('29 a) \\
\hline Ibid., 1 cul de sac & All parts & $0.00 \pm 0.13$ & Lashley ('29 a) \\
\hline Mbid., 4 culs de sac & All parts & $0.80 \pm 0.05$ & Lashley and Wiley ('32) \\
\hline Ihid., 8 culs de sac & All parts & $0.80 \pm 0.05$ & Lashley and Wiley ('32) \\
\hline Ibid., 12 culs de sac & All parts & $0.70 \pm 0.07$ & rashley and Wiley ('32) \\
\hline Ibid,, 16 culs de sae & All parts. & $0.60 \pm 0.08$ & Lashley and Wiley ('32) \\
\hline Ibid., 8 culs de sac reversed & All parts & $0.64 \pm 0.04$ & Lashley and Wiley ('32) \\
\hline
\end{tabular}


It is the purpose of the present investigation to determine the deterioration in behavior resulting when various patterns of cortical tissue are destroyed.

\section{METHOD AND PROCEDURE}

\section{A. The psychological function studied}

To test the deterioration resulting when various patterns of cortical tissue are destroyed, some psychological function must be tested. The function selected for this investigation is one which I have termed reasoning ability (Maier, '31). This ability was selected because small lesions readily interfere with it and because it is a general ability which satisfies the conditions of mass action. Reasoning ability may be specifically defined as the ability to combine spontaneously two or more separate or isolated experiences to form a new experience which is effective for obtaining a desired end. In other words, if we present an animal with a problem which can be solved by a reorganization of past experiences, but cannot be solved by habit or 'trial and error,' we will have set up a reasoning situation. I have previously investigated this ability in some detail (Maier, '29, '32 b) and have developed the following simple test situation to measure it.

From a table in the center of a room three strips of wood (2 inches wide) form runways which lead to three different tables which are placed in a circle about the center table. The outer tables are equally distant from each other and each is 6 feet from the center table. Each of the outer tables has a screen so attached that the animal tested cannot see from one table to the other. With this arrangement it is possible for an animal to run from any one of the three outer tables to either of the other two by going by way of the center table. All of the animals are made familiar with the tables and pathways through exploration before experimentation is begun.

The testing procedure in this study was as follows: both the animal and the food were placed on one of the outer tables and the animal permitted to eat a few bites of food; it was 
then removed and placed on one of the other outer tables. By this means the animal was confronted with the problem of obtaining food when placed in the new position. If it went directly to the table containing food the run was scored correct, if it went to the other table the run was scored incorrect. By using different combinations of tables on successive days the same problem could be repeated any number of times.

\section{B. Scoring of tests}

Each of our animals was tested a total of eighteen times both before and after operation. Because half of these would be correct by chance, a successful animal would have to run correctly more than nine times. In computing the percentage of correct responses for the groups of rats a chance score was reduced to zero per cent by dividing the difference between the correct and incorrect responses by the total number of responses.

\section{The subjects used}

Albino and black-hooded male and female rats ranging in age from 8 to 18 months were used as subjects. Rats were the most satisfactory subjects for our purposes because their abilities in relation to mass action have been experimentally studied more than any other animal. As sex, coloring and exact age of adult subjects have been found (Maier, '32 a, '32 b) to have little or no effect on the test scores, these differences in our subjects have been disregarded.

\section{The lesion patterns compared}

Ordinarily, a cortical lesion is produced on each hemisphere by entering the skull through a single trephine opening. In such cases the pattern of destruction has the trephine opening as a center. If, as alternatives, two or three trephine openings are made over each hemisphere and tissue destroyed about each of the openings the pattern of destruction will either consist of two or three separate areas, or, if the areas 
join, take on an elongated form. In any case, the more trephine openings used, the greater the perimeter of the lesion pattern, although the area of destruction need be no greater.

In this study the rats were divided into three groups. Group 1 had cortical tissue destroyed through one pair of trephine openings; group 2, through two pairs of openings; and group 3, through three pairs of openings. In all cases an attempt was made to destroy corresponding parts of each hemisphere through each pair of trephine openings.

The lesions were all confined to some part of the dorsal surface of the brain because I had previously explored the function of this surface in reasoning ability (Maier, ' $32 \mathrm{~b}$, ' $32 \mathrm{c}$ ). When one pair of trephine openings was used, it was sometimes anterior, sometimes posterior, and sometimes between. When three pairs of opening's were used, the openings were about equally spaced on the dorsal surface.

\section{E. Procedure}

All rats were tested before operation a total of eighteen times. One test run was made each successive day, with the exception of every seventh day when a day's rest was given to prevent inattention which arises when the monotony is not broken (Maier, '30). The actual testing period thus extended over a period of 20 days. Previous to the beginning of the testing program the rats were given 5 minutes' free exploration on 10 successive days. At the end of each exploration period the rats were fed on the center table. After the testing was begun, 5 minutes of free exploration preceded the test on each day.

Following the pre-operative test period, the rats were divided into the three groups described above and subjected to cortical operations under deep ether anaesthesia. Tissue was destroyed by thermo-cautery. An attempt was made to vary the extent of destruction in each of the three groups of rats and to keep the average amount and the range of destruction about the same for the three groups. 
Twenty-three out of twenty-five rats in group 1 , twentyfour out of twenty-five in group 2, and nineteen out of twenty in group 3 survived the operation. One of the rats in group 2 is not included in this study, because it failed to pass the tests before operation.

After the operation the rats were allowed from 6 to 9 days for recovery. They were then given 5 minutes per day for 6 successive days in which to explore the tables and exercise themselves. The experimenter encouraged the more quiet rats to run on the poles by placing them on poles mid-way between the tables. At the end of the exploration period they were fed on the center table as before. Following this period of exploration, the original test period was repeated.

After the rats had completed the post-operative tests they were killed and their brains removed for histological examination. From the sections the brains were reconstructed according to the dimensions of an average rat's brain and the lesions measured according to the methods of Lashley ('29).

\section{RESULTS}

A. A comparison of the scores made by rats with different types of lesions

The data obtained from the individual rats in groups 1,2 and 3 are given in tables 2,3 and 4, respectively. The first column gives the experimental number and sex of the animals; the second column, the total percentage of destruction; the third column, the percentage of destruction which is common to both hemispheres; the fourth and fifth columns, the number of correct and the number of incorrect responses, respectively, in the eighteen tests given before operation; and the sixth and seventh columns the same for the eighteen tests given after operation.

A comparison of the tables shows that the range and the average amount of destruction are about the same for each group, the average amounts of destruction for groups 1, 2 and 3 being 21.5, 22.6 and 21.2 per cent of the total cortical surface, respectively. In table 4 (group 3 ) the data obtained 
from the first two cases have not been included in any of the calculations. The first of these (rat $34 \mathrm{M}$ ) suffered no cortical lesion. It was a control case in which only the trephine openings were introduced. The second rat (no. 3F) suffered a very small lesion and is excluded in order to make the groups comparable.

TABLE 2

Scores made by rats in group 1 (one pair trephine openings)

\begin{tabular}{|c|c|c|c|c|c|c|}
\hline \multirow[b]{2}{*}{ RAq } & \multicolumn{2}{|c|}{ PER CENT OF DESTRUCTION } & \multicolumn{2}{|c|}{ SCORE BETORE OPERATION } & \multicolumn{2}{|c|}{ SCORE APTER OPRRATION } \\
\hline & $\begin{array}{l}\text { Total } \\
\text { lesion }\end{array}$ & $\begin{array}{c}\text { Common } \\
\text { lesion }\end{array}$ & Correct & incorrect & Correct & Incorrect \\
\hline $63 \mathrm{~F}$ & 13.1 & 9.2 & 18 & 0 & 15 & 3 \\
\hline $65 \mathrm{~F}$ & 13.2 & 8.1 & 17 & 1 & 18 & 0 \\
\hline $76 \mathrm{M}$ & 13.8 & 12.3 & 16 & 2 & 13 & 5 \\
\hline $69 \mathrm{M}$ & 14.9 & 10.9 & 17 & 1 & 14 & 4 \\
\hline $75 \mathrm{M}$ & 16.3 & 12.4 & 17 & 1 & 13 & 5 \\
\hline $71 \mathrm{M}$ & 16.7 & 14.8 & 15 & 3 & 17 & 1 \\
\hline $66 \mathrm{~F}$ & 17.6 & 11.9 & 18 & 0 & 11 & 7 \\
\hline $88 \mathrm{M}$ & 17.7 & 16.0 & 18 & 0 & 13 & 5 \\
\hline $67 \mathrm{~F}$ & 18.5 & 16.0 & 17 & 1 & 14 & 4 \\
\hline $61 \mathrm{~F}$ & 18.7 & 14.8 & 17 & 1 & 11 & 7 \\
\hline $64 \mathrm{~F}$ & 20.8 & 16.2 & 17 & 1 & 11 & 7 \\
\hline $73 \mathrm{M}$ & 23.3 & 19.7 & 18 & 0 & 17 & 1 \\
\hline $85 \mathrm{M}$ & 23.5 & 20.6 & 17 & 1 & 14 & 4 \\
\hline $96 \mathrm{~F}$ & 23.9 & 16.0 & 17 & 1 & 12 & 6 \\
\hline $74 \mathrm{M}$ & 24.5 & 18.0 & 17 & 1 & 15 & 3 \\
\hline $95 \mathrm{~F}$ & 25.0 & 18.5 & 18 & 0 & 15 & 3 \\
\hline $92 \mathrm{~F}$ & 25.2 & 18.5 & 15 & 3 & 11 & 7 \\
\hline $94 \mathrm{~F}$ & 26.7 & 20.5 & 16 & 2 & 14 & 4 \\
\hline $83 \mathrm{M}$ & 26.7 & 21.1 & 16 & 2 & 14 & 4 \\
\hline $84 \mathrm{M}$ & 27.7 & 21.7 & 15 & 3 & 7 & 11 \\
\hline $91 \mathrm{~F}$ & 28.1 & 23.4 & 16 & 2 & 12 & 6 \\
\hline $82 \mathrm{M}$ & 28.3 & 20.9 & 12 & 6 & 9 & 9 \\
\hline $86 \mathrm{M}$ & 29.7 & 22.9 & 16 & 2 & 10 & 8 \\
\hline \multirow[t]{3}{*}{ Average } & 21.5 & 16.7 & 16.52 & 1.48 & 13.04 & 4.96 \\
\hline & & & $83.6 \%$ & & $44.9 \%$ & \\
\hline & & , & \multicolumn{4}{|c|}{$46.3 \%$ reduction } \\
\hline
\end{tabular}

The pre-operative scores made by groups 1,2 and 3 are 83.6, 76.4 and 84.3 per cent correct, respectively. These scores are nearly enough alike to regard the abilities of the groups to be approximately equal. The post-operative scores are, how- 
ever, quite different. For group 1 it is 44.9 per cent correct, for group 2, 56.9 per cent correct, and for group 3, 71.2 per cent correct. The percentages of reduction from the preoperative to the post-operative scores for these groups are

TABLE 3

Scores made by rats in group 2 (two pair trephine openings)

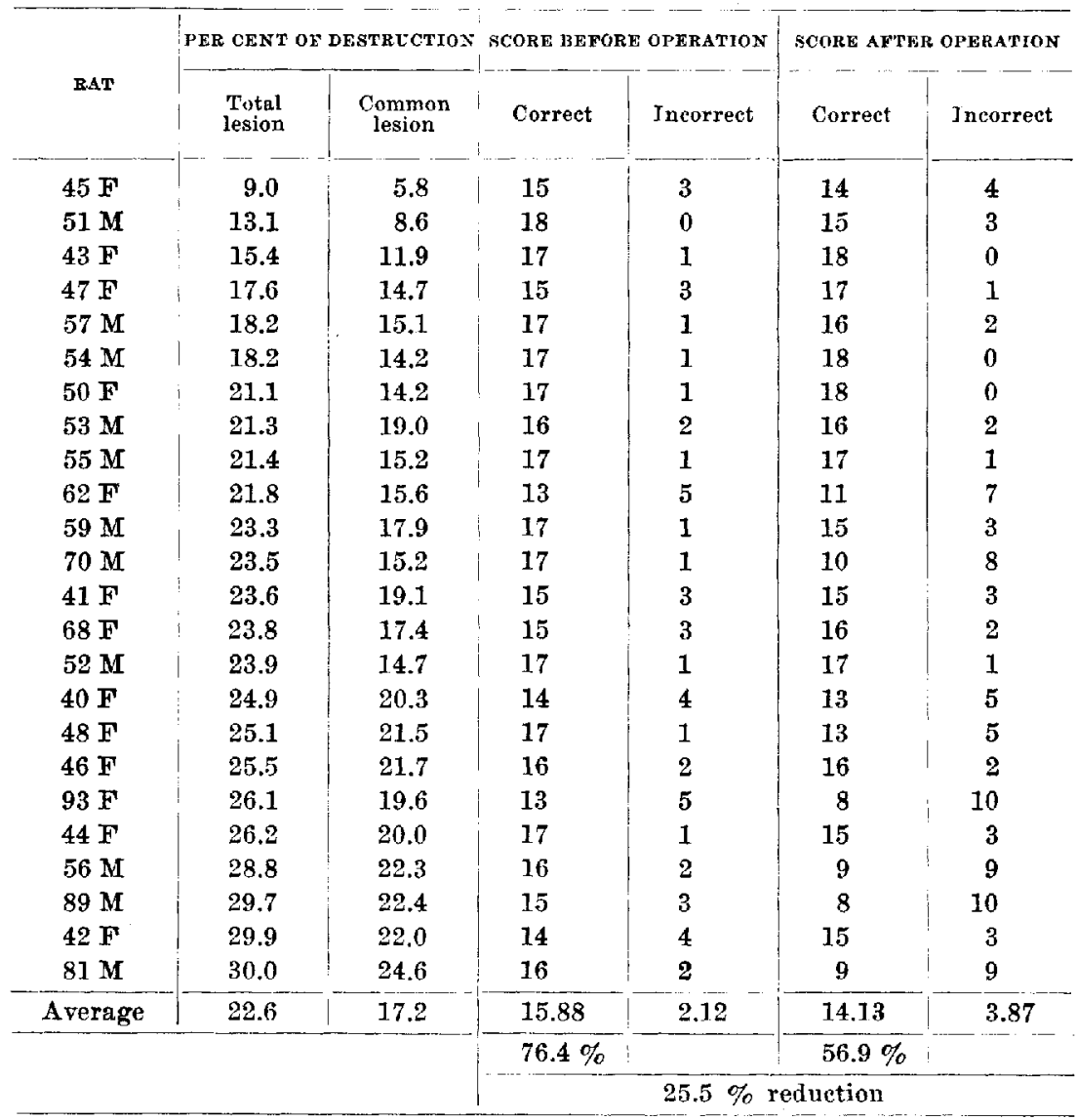

$46.3,25.5$ and 15.5, respectively. All groups show a marked reduction in ability, but the amount of reduction varies greatly for the three groups. As the groups were similar in the amount of cortical surface destroyed, but different in the number of trephine openings used to destroy the tissue, 
it must be concluded that this difference in some way resulted in different degrees of deterioration. Increasing the number of trephine openings through which tissue was destroyed resulted in a decrease in the amount of deterioration.

TABLE 4

Scores made by rats in group 3 (three pair trephine openings)

\begin{tabular}{|c|c|c|c|c|c|c|}
\hline \multirow[b]{2}{*}{ RAT } & \multicolumn{2}{|c|}{ PER CENT OF DESTRCCTION } & \multicolumn{2}{|c|}{ SCORE BEFORE OPERATION } & \multicolumn{2}{|c|}{ SCURE AFTER CPERATION } \\
\hline & $\begin{array}{l}\text { Total } \\
\text { lesion }\end{array}$ & $\begin{array}{l}\text { Common } \\
\text { lesion }\end{array}$ & Correct & Incorrect & Correct & Incorrect \\
\hline $34 M^{1}$ & 0.0 & 0.0 & 17 & 1 & 18 & 0 \\
\hline $3 \mathrm{~F}^{\mathrm{u}}$ & 5.9 & 3.5 & 17 & 1 & 18 & 0 \\
\hline $31 \mathrm{M}$ & 10.5 & 9.4 & 18 & 0 & 17 & 1 \\
\hline $6 \mathrm{~F}$ & 14.9 & 12.3 & 18 & 0 & 16 & 2 \\
\hline $30 \mathrm{M}$ & 16.1 & 12.8 & 17 & 1 & 15 & 3 \\
\hline $25 \mathrm{M}$ & 16.8 & 10.3 & 15 & 3 & 14 & 4 \\
\hline $24 \mathrm{M}$ & 17.7 & 10.1 & 16 & 2 & 17 & 1 \\
\hline $5 \mathrm{~F}$ & 19.7 & 10.6 & 16 & 2 & 15 & 3 \\
\hline $22 \mathrm{M}$ & 20.3 & 14.7 & 16 & 2 & 17 & 1 \\
\hline $21 \mathrm{M}$ & 21.2 & 14.5 & 13 & 5 & 16 & 2 \\
\hline $36 \mathrm{~F}^{\prime}$ & 21.4 & 18.3 & 18 & 0 & 17 & 1 \\
\hline $37 \mathrm{~F}$ & 21.5 & 16.0 & 17 & 1 & 15 & 3 \\
\hline $33 \mathrm{M}$ & 21.9 & 13.8 & 17 & 1 & 16 & 2 \\
\hline $35 \mathrm{M}$ & 22.4 & 15.3 & 16 & 2 & 17 & 1 \\
\hline $23 \mathrm{M}$ & 23.9 & 20,3 & 15 & 3 & 10 & 8 \\
\hline $2 \mathbf{F}$ & 25.2 & 18.9 & 16 & 2 & 18 & 0 \\
\hline $1 \mathrm{~F}$ & 28.0 & 23.6 & 18 & 0 & 15 & 3 \\
\hline $32 \mathrm{M}$ & 29.2 & 23.4 & 18 & 0 & 16 & 2 \\
\hline $4 \mathrm{~F}$ & 30.0 & 25.0 & 18 & 0 & 11 & 7 \\
\hline \multirow[t]{3}{*}{ Average } & 21.2 & 15.7 & 16.59 & 1.41 & 15.41 & 2.59 \\
\hline & & & $84.3 \%$ & & $71.2 \%$ & \\
\hline & & & & $15.5 \%$ & luction & \\
\hline
\end{tabular}

${ }^{2}$ In order that the lesions of group 3 be comparable with those of groups 1 and 2, these cases are excluded from the averages.

Plates 1, 2 and 3 reproduce the lesions of each individual rat. The black portion represents the area destroyed which is common to both hemispheres, the stippled portion the asymmetrical areas destroyed. The lateral aspects of the brain are not shown. In a number of cases (rats $66,88,64,96,83$, $94,91,82$ and 86 of group 1, rats 50, 93, 89 and 81 of group 2) 
the lesions extended slightly in to the lateral parts of the brain which are invisible from the dorsal view. The extent of the destruction into these lateral portions are given for each case in the discussion of the plates (p.433). As these cases are relatively few in number and never involved more than 1.7 per cent of the lateral brain surfaces, it seemed advisable, for the sake of economy, to merely indicate such eases rather than to reproduce the whole brain surface.

Figure 1 represents the composite lesions for each of the three groups of rats. It will be noted that groups 2 and 3
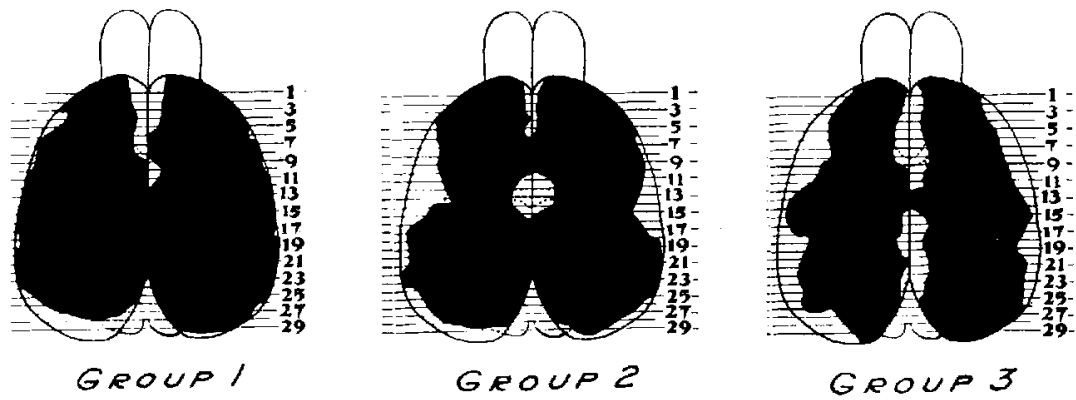

Fig. 1 Composite lesions of rats in groups 1,2 and 3 . Only the dorsal aspects of the brains are represented. The lateral aspects, not visible in the figure, were invaded but slightly. The composite invasion in both lateral as pects was 4.2 per cent of the total brain surface in the case of group $1 ; 0.9$ per cent in the ease of group 2 ; and zero for group 3.

include approximately the same areas as group 1. The composite lesion of group 1 extends into the lateral surface not shown in the figure to an extent of 4.2 per cent of the total brain surface, group 2, to an extent of 0.9 per cent; and group 3 , not at all.

\section{$B$. The relation between size of lesion and scores malle}

If we divide each of the groups of rats (tables 2,3 and 4) into three parts according to the magnitude of their lesions, we can obtain some idea of the relation between the size of lesion and the scores made on the post-operative tests. In table 5 , the rats of tables 2,3 and 4 have been divided into 
the following three parts: a) those with lesions ranging from 9 through 17 per cent; b) those with lesions ranging from 18 through 24 per cent; and those with lesions ranging from 25 through 30 per cent.

For rats in group 1 the post-operative scores are 58.3, 49.2 and 27.8 per cent correct as we go from the smaller to the larger lesions. For rats in groups 2 and 3 the corresponding figures are 77.8, 68.5 and 29.9; and 75.6, 70.8 and 66.7.

TABLE 5

\begin{tabular}{|c|c|c|c|c|}
\hline \multicolumn{4}{|c|}{ Score versus size of lesion } & \multirow{2}{*}{$\begin{array}{l}\text { DIFFERENCE IN } \\
\text { SCORE }\end{array}$} \\
\hline LESIONS & $\begin{array}{l}\text { NUMBER OF } \\
\text { CASES }\end{array}$ & $\begin{array}{l}\text { PRA-OFERATIVE } \\
\text { SCORE }\end{array}$ & $\begin{array}{c}\text { POST-OPERATIVE } \\
\text { SCORE }\end{array}$ & \\
\hline \multicolumn{5}{|c|}{ Group 1} \\
\hline Per cent & & Per cent & Per cent & Per cent \\
\hline $9-17$ & 8 & 88.9 & 58.3 & 30.6 \\
\hline $18-24$ & 7 & 90.5 & 49.2 & 41.3 \\
\hline $25-30$ & 8 & 72.2 & 27.8 & 44.4 \\
\hline \multicolumn{5}{|c|}{ Group 2} \\
\hline $9-17$ & 4 & 80.6 & 77.8 & 2.8 \\
\hline $18-24$ & 12 & 77.8 & 68.5 & 9.3 \\
\hline $25-30$ & 8 & 72.2 & 29.9 & 42.3 \\
\hline \multicolumn{5}{|c|}{ Group 3} \\
\hline $9-17$ & 5 & 84.8 & 75.6 & 9.2 \\
\hline $18-24$ & 8 & 77.8 & 70.8 & 7.0 \\
\hline $25-30$ & 4 & 94.4 & 66.7 & 27.7 \\
\hline
\end{tabular}

These figures show that in the case of each group of rats there is a relationship between the amount of destruction and the post-operative score. This relationship is in the direction which one would expect it to be according to the concept of mass action. However, the falling off in score as we go from the smaller to the larger lesions is most rapid for rats in group 1 and least rapid for rats in group 3. Small lesions for rats in group 1 produce a marked reduction in score. For rats in group 2 only the large lesions produce a marked reduction. For rats in group 3 none of the groups of lesions studied produces a marked reduction. 
These data show that, although the amount of destruction is an important consideration, it is not the only factor determining the degree of deterioration. Some difference in the lesions of the three groups of rats must be responsible for these differences found.

\section{The effect of total versus symmetrical destruction}

In considering the differences between the three groups of rats, it might be supposed that in introducing the lesions in different manners, one method might result in more symmetrical lesions than another. Thus in entering the skull through one pair of trephine openings one might be more likely to strike corresponding structures than in entering through more pairs of trephine openings. This supposition, of course, presupposes that the effect of a lesion is partially a function of the symmetry of the lesion.

Tables 2, 3 and 4 show both the total and the symmetrical percentages of destruction. The difference in these averages is 4.8 per cent for group 1, 5.4 per cent for group 2, and 5.5 per cent for group 3. Plates 1,2 and 3 represent the symmetrical destruction with solid black areas and the asymmetrical destruction with stippled areas.

In order to determine the relative effect of symmetrical and asymmetrical lesions, the relationship between total mass of destruction and errors can be compared with the relationship between the total mass of destruction which is common to both hemispheres and errors. The extent of these relationships was determined by calculating correlation coefficients for each of the three groups of rats. (Pearson's formula was used.)

In table 6 these correlation coefficients and their probable errors are given. It will be noted that the coefficients tend to be smaller when the symmetrical mass and post-operative errors are correlated than when total mass and errors are correlated. This shows that the total per cent of destruction is a better index of the extent of damage done than the percentage of destruction which is common to both hemispheres. 
This conclusion is in harmony with the findings of Lashley and Wiley ('33) in their study of the effect of cortical destruction on maze learning. We may therefore conclude that the differences in scores between our three groups of rats is not due to any differences in the symmetry of their lesions.

\section{A comparison of the spacing of the lesions}

On examining the lesions in plates 2 and 3 it will be seen that many of the lesions are divided into two or more parts. This might suggest that a lesion is perhaps less effective when normal tissue lies between the parts of the lesion. Inspection, however, readily shows that the rats in group 2 have

TABLE 6

Correlation coefficients

\begin{tabular}{l|c|c}
\hline & $\begin{array}{c}\text { TOTal Mass } \\
\text { v.s. ERRORs }\end{array}$ & $\begin{array}{c}\text { SYMMETRIOAL Mass } \\
\text { v.s. ERRORs }\end{array}$ \\
\hline Group 1 (one pair trephine openings & $0.52 \pm 0.10$ & $0.40 \pm 0.12$ \\
Group 2 (two pair trephine openings) & $0.52 \pm 0.11$ & $0.45 \pm 0.11$ \\
Group 3 (three pair trephine openings) & $0.34 \pm 0.14$ & $0.39 \pm 0.14$ \\
\hline
\end{tabular}

this spacing to the greatest extent. The score of this group lies part way between the scores made by the other two groups. It can, therefore, not be concluded that the separation of a lesion into two or more parts is responsible for the differences between the groups.

$E$. The effect of sub-cortical injuries on scores

When entering the brain from one trephine opening and attempting large lesions, one may be more likely to involve sub-cortical structures than when entering from more points. In order to exclude the possibility that sub-cortical structures contributed to our results, it is necessary to analyze the results with this in mind. In all cases in which sub-cortical destruction was present, it was very slight and for this reason the cases cannot be grouped according to the degree of such destruction. The most successful approach seemed to be that of separating each of the three gromps of rats into, 
a) cases without sub-cortical injuries and, b) cases with subcortical injuries. This division of the cases is shown in table 7. In each of the groups, the rats with sub-cortical injuries make poorer scores than the rats without such in-

TABLE 7

The effect of sub-cortical injuries on scores

\begin{tabular}{|c|c|c|c|c|c|c|c|c|}
\hline \multicolumn{3}{|c|}{ GROUP 1} & \multicolumn{3}{|c|}{ GROUP 2} & \multicolumn{3}{|c|}{ GROUP 3} \\
\hline Rat & $\begin{array}{l}\text { Percent } \\
\text { destruc- } \\
\text { tion }\end{array}$ & $\begin{array}{l}\text { Correct } \\
\text { runs. }\end{array}$ & Rat & $\begin{array}{l}\text { Per cent } \\
\text { destruc- } \\
\text { tion }\end{array}$ & $\begin{array}{l}\text { Correct } \\
\text { runs }\end{array}$ & Rat & $\begin{array}{l}\text { Per cent } \\
\text { destruc- } \\
\text { tion }\end{array}$ & $\begin{array}{l}\text { Correct } \\
\text { runs }\end{array}$ \\
\hline
\end{tabular}

Cases withont sub-cortical injuries

\begin{tabular}{|c|c|c|c|c|c|c|c|c|}
\hline $63 \mathrm{~F}$ & 13.1 & 15 & $45 \mathrm{~F}$ & 9.0 & 14 & $31 \mathrm{M}$ & 10.5 & 17 \\
\hline $69 \mathrm{M}$ & 14.9 & 14 & $51 \mathrm{M}$ & 13.1 & 15 & $6 \mathrm{~F}$ & 14.9 & 16 \\
\hline $75 \mathrm{M}$ & 16.3 & 13 & $43 \mathbf{F}$ & 15.4 & 18 & $30 \mathrm{M}$ & 16.1 & 15 \\
\hline $71 \mathrm{M}$ & 16.7 & 17 & $54 \mathrm{M}$ & 18.2 & 18 & $25 \mathrm{M}$ & 16.8 & 14 \\
\hline $67 \mathrm{~F}$ & 18.5 & 14 & $55 \mathrm{M}$ & 21.4 & 17 & $24 \mathrm{M}$ & 17.7 & 17 \\
\hline $85 \mathrm{M}$ & 23.5 & 14 & $70 \mathrm{M}$ & 23.5 & 10 & $22 \mathrm{M}$ & 20.3 & 17 \\
\hline $96 \mathrm{~F}$ & 23.9 & 12 & $52 \mathrm{M}$ & 23.9 & 17 & $21 \mathrm{M}$ & 21.2 & 16 \\
\hline \multirow[t]{3}{*}{$74 \mathrm{M}$} & 24.5 & 15 & $93 \mathrm{~F}$ & 26.1 & 8 & $36 \mathrm{~F}$ & 21.4 & 17 \\
\hline & & & & & & $35 \mathrm{M}$ & 22.4 & 17 \\
\hline & & & & & & $1 \mathrm{~F}$ & 28.0 & 15 \\
\hline \multirow[t]{2}{*}{ Average } & 18.9 & 14.2 & & 18.8 & 14.6 & & 18.9 & 16.1 \\
\hline & I & $58.3 \%$ & & & $62.5 \%$ & & & $78.9 \%$ \\
\hline
\end{tabular}

Cases with sub-cortical injuries (slight in all eases)

\begin{tabular}{|c|c|c|c|c|c|c|c|c|}
\hline $65 \mathrm{~F}$ & 13.2 & 18 & $47 \mathbf{F}$ & 17.6 & 17 & $5 F$ & 19.7 & 15 \\
\hline $76 \mathrm{M}$ & 13.8 & 13 & $57 \mathrm{M}$ & 18.2 & 16 & $37 \mathrm{~F}$ & 21.5 & 15 \\
\hline $66 \mathrm{~F}$ & 17.6 & 11 & $50 \mathrm{~F}$ & 21.1 & 18 & $33 \mathrm{M}$ & 21.9 & 16 \\
\hline $88 \mathrm{M}$ & 17.7 & 13 & $53 \mathrm{M}$ & 21.3 & 16 & $23 \mathrm{M}$ & 23.9 & 10 \\
\hline $61 \mathrm{~F}$ & 18.7 & 11 & $62 \mathrm{~F}$ & 21.8 & 11 & $2 \mathrm{~F}$ & 25.2 & 18 \\
\hline $64 \mathrm{~F}$ & 20.8 & 11 & $59 \mathrm{M}$ & 23.3 & 15 & $32 \mathrm{M}$ & 29.2 & 16 \\
\hline $73 \mathrm{M}$ & 23.3 & 17 & $41 \mathrm{~F}$ & 23.6 & 15 & $4 \mathrm{~F}$ & 30.0 & 11 \\
\hline $95 \mathrm{~F}^{\prime}$ & 25.0 & 15 & $68 \mathrm{~F}$ & 23.8 & 16 & & & \\
\hline $92 \mathrm{~F}$ & 25.2 & 11 & $40 \mathrm{~F}$ & 24.9 & 13 & & & \\
\hline $83 \mathrm{M}$ & 26.7 & 14 & $48 \mathrm{~F}$ & 25.1 & 13 & & & \\
\hline $94 \mathbf{F}$ & 26.7 & 14 & $46 \mathrm{~F}$ & 25.5 & 16 & & & \\
\hline $84 \mathrm{M}$ & 27.7 & 7 & $44 \mathrm{~F}$ & 26.2 & 15 & & & \\
\hline $91 F$ & 28.1 & 12 & $56 \mathrm{M}$ & 28.8 & 9 & & & \\
\hline $82 \mathrm{M}$ & 28.3 & 9 & $89 \mathrm{M}$ & 29.7 & 8 & & & \\
\hline $86 \mathrm{M}$ & 29.7 & 10 & $42 \mathrm{~F}$ & 29.9 & 15 & & & \\
\hline & & & $81 \mathrm{M}$ & 30.0 & 9 & & & \\
\hline \multirow[t]{2}{*}{ Average } & 22.8 & 12.4 & & 24.4 & 13.9 & & 24.5 & 14.4 \\
\hline & \multicolumn{3}{|c|}{$37.8 \%$} & & 54.2 & & & $60.3 \%$ \\
\hline
\end{tabular}


juries, but the average cortical lesion of the cases with subcortical injuries is larger than that of the cases without subcortical injuries. Whether or not this difference in the cortical injury accounts for the difference in score cannot be determined from these results. Previous studies (Lashley, '29; and Maier, '32 b, '32 c) show that sub-cortical destruction contributes little or not at all to the errors in learning and in reasoning tests. As reasoning scores fall off rapidly when the extent of injury falls between 18 and 25 per cent of the cortical surface (Maier, '32 b, '32 c), it seems quite likely that the extra cortical tissue destroyed in the cases with subcortical injury is responsible for the difference in scores obtained.

On the other hand, we can compare the cases without subcortical destruction of each of the three groups with each other. When this is done, we note that the average scores for groups 1, 2 and 3 are 58.3 per cent, 62.5 per cent and 78.9 per cent, respectively. In a similar manner the cases with sub-cortical injuries in each of the three groups can be compared. For these cases the average scores for groups 1, 2 and 3 are 37.8 per cent, 54.2 per cent and 60.3 per cent. These comparisons do not involve marked differences in the extent of cortical injury. Where there are differences in the extent of injury, they are in the direction opposite to the one which would explain the increase in score.

Because the same differences between the groups are present when we compare either cases with or without sub-cortical injuries, it is possible to conclude that differences in subcortical injuries between the groups are not responsible for the character of our results.

\section{$F$. The relation between the pattern of the lesion and post-operative scores}

The lesions of the three groups of rats varied in one obvious respect. Those of group 1 tended to be round and those of groups 2 and 3, to be elliptical. Thus as the number of trephine openings increased the relative lengths of the lesions 
increased. In order to obtain a rough comparison of the lesions in this respect, the ratio between the greatest length and the width of each lesion was computed. In cases where the lesions were separated into two or more parts, the lengths of the separate parts were added to give the total length.

TABLE 8

The ratio of length to wiath of lesion

\begin{tabular}{|c|c|c|c|c|c|}
\hline \multicolumn{2}{|c|}{ GROUP 1} & \multicolumn{2}{|c|}{ GROUP 2} & \multicolumn{2}{|c|}{ GROUP 3} \\
\hline Rat & Ratio $\mathrm{L} / \mathrm{W}$ & Rat & Ratio L/W & Rat & Ratio L/W \\
\hline $63 \mathrm{~F}$ & 1.3 & $45 \mathrm{~F}$ & 1.8 & $31 \mathrm{M}$ & 3.5 \\
\hline $65 \mathbf{F}$ & 1.0 & $51 \mathrm{M}$ & 1.9 & $6 \mathrm{~F}$ & 3.1 \\
\hline $76 \mathrm{M}$ & 1.3 & $43 \mathrm{~F}$ & 2.3 & $30 \mathrm{M}$ & 2.2 \\
\hline $69 \mathrm{M}$ & 1.1 & $47 \mathrm{~F}$ & 2.2 & $25 \mathrm{M}$ & 3.1 \\
\hline $75 \mathrm{M}$ & 1.4 & $57 \mathrm{M}$ & 1.9 & $24 \mathrm{M}$ & 2.8 \\
\hline $71 \mathrm{M}$ & 1.6 & $54 \mathbf{M}$ & 1.6 & $5 F$ & 2.4 \\
\hline $66 \mathrm{~F}$ & 1.4 & $50 \mathrm{~F}$ & 2.0 & $22 \mathrm{M}$ & 2.4 \\
\hline $88 \mathrm{M}$ & 1.0 & $53 \mathrm{M}$ & 1.6 & $21 \mathrm{M}$ & 2.6 \\
\hline $67 F$ & 1.4 & $55 \mathrm{M}$ & 1.8 & $36 \mathbf{F}$ & 2.3 \\
\hline $61 \mathrm{~F}$ & 1.2 & $62 F$ & 1.7 & $37 \mathbf{F}$ & 2.3 \\
\hline $64 \mathrm{~F}$ & 1.2 & $59 \mathrm{M}$ & 1.9 & $33 \mathrm{M}$ & 2.4 \\
\hline $73 \mathrm{M}$ & 1.4 & $70 \mathrm{M}$ & 2.3 & $35 \mathrm{M}$ & 3.2 \\
\hline $85 \mathrm{M}$ & 1.5 & $41 \mathrm{~F}$ & 2.1 & $23 \mathrm{M}$ & 2.3 \\
\hline $96 \mathrm{~F}$ & 1.1 & $68 \mathrm{~F}$ & 1.7 & $2 F$ & 3.0 \\
\hline $74 \mathrm{M}$ & 1.2 & $52 \mathrm{M}$ & 1.8 & $1 \mathrm{~F}$ & 2.5 \\
\hline $95 \mathrm{~F}$ & 2.0 & $40 F$ & 2.6 & $32 \mathrm{M}$ & 2.5 \\
\hline $92 \mathbf{F}$ & 1.2 & $48 \mathrm{~F}$ & 2,0 & $4 F$ & 2.5 \\
\hline $94 \mathrm{~F}$ & 1.8 & $46 \mathrm{~F}$ & 1.9 & & \\
\hline $83 \mathrm{M}$ & 1.4 & $93 \mathrm{~F}$ & 1.4 & & \\
\hline $84 \mathrm{M}$ & 1.4 & $44 \mathrm{~F}$ & 2.0 & & \\
\hline $91 \mathrm{~F}$ & 1.3 & $56 \mathrm{M}$ & 1.9 & & \\
\hline $82 \mathrm{M}$ & 1.5 & $89 \mathrm{M}$ & 1.6 & & \\
\hline $86 \mathrm{M}$ & 1.2 & $42 \mathrm{~F}$ & 2.0 & & \\
\hline & & $81 \mathrm{M}$ & 1.9 & & \\
\hline Average & 1.34 & & 1.91 & & 2.64 \\
\hline
\end{tabular}

The results of these computations for each rat in each of the three groups of rats are given in table 8 . It will be seen that the average ratio increases progressively as the number of trephine openings increases; the average ratios for groups 1,2 and 3 being $1.34,1.91$ and 2.64, respectively. Because the average per cent of destruction and distribution of the sizes 
of the lesions were nearly the same for the three groups (tables 2, 3 and 4), it is possible to compare the groups on the basis of the relationship between the score made and the lesion ratio.

In figure 2 we have plotted the lesion ratio along the horizontal axis and the per cent of correct responses along the

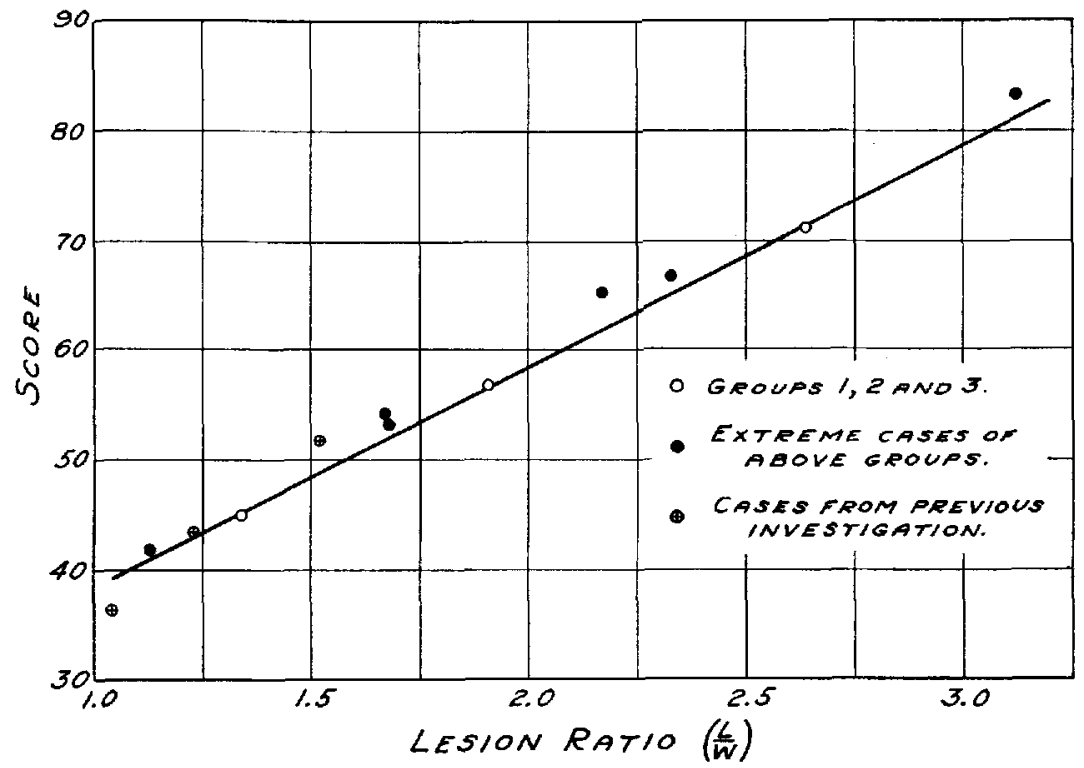

Fig. 2 The curve shows the relationship between reasoning test score and lesion pattern when the amount of cortical destruction remains the same. The lesion pattern was characterized by finding the ratio between the greatest length and the greatest width of each lesion. The seore is given in terms of the per cent correct after correcting for chance. Points not lying on the curve represent cases having extreme lesion ratios in each of the groups of rats used in this study and data obtained in a previous investigation.

vertical axis for each of the three groups. The points for the three groups are indicated by open circles in the figure. It will be noted that these points fall almost exactly on a straight line. It seems that when the amount of destruction remains constant, the loss in ability is directly related to the ratio between the length and width of the lesion. An increase in the relative length of lesions results in a decrease in deterioration. 
If these findings are reliable, it follows that similar differences in score should result if each group of rats is divided into, a) those cases with lesion ratios smaller than the average, and, b) those cases with lesion ratios larger than the average. Thus for group 1 the cases with lesion ratios less than 1.3 and those with lesion ratios greater than 1.4 are compared; for group 2 the cases with lesion ratios less than

TABLE 9

Records of rats in group 1 with lesion ratios above and below the average ratio

\begin{tabular}{|c|c|c|c|}
\hline $\mathrm{RAT}$ & $\begin{array}{l}\text { LESION } \\
\text { RATIO }\end{array}$ & $\begin{array}{l}\text { PER CENT } \\
\text { DESTRUOTION }\end{array}$ & $\begin{array}{l}\text { CORRECT } \\
\text { RUNS }\end{array}$ \\
\hline \multicolumn{4}{|c|}{ Cases with lesion ratios less than 1.3} \\
\hline $65 \mathrm{~F}$ & 1.0 & 13.2 & 18 \\
\hline $69 \mathrm{M}$ & 1.1 & 14.9 & 14 \\
\hline $88 \mathrm{M}$ & 1.0 & 17.7 & 13 \\
\hline $61 \mathrm{~F}$ & 1.2 & 18.7 & 11 \\
\hline $64 \mathrm{~F}$ & 1.2 & 20.8 & 11 \\
\hline $96 \mathrm{~F}$ & 1.1 & 23.9 & 12 \\
\hline $74 \mathrm{M}$ & 1.2 & 24.5 & 15 \\
\hline $92 \mathrm{~F}$ & 1.2 & 25.2 & 11 \\
\hline $86 \mathrm{M}$ & 1.2 & 29.7 & 10 \\
\hline Average & 1.13 & 20.9 & 12.8 or $42,0 \%$ \\
\hline \multicolumn{4}{|c|}{ Cases with lesion ratios greater than 1.4} \\
\hline $71 \mathrm{M}$ & 1.6 & 16.7 & 17 \\
\hline $85 \mathrm{M}$ & 1.5 & 23.5 & 14 \\
\hline $95 \mathrm{~F}$ & 2.0 & 25.0 & 15 \\
\hline $94 \mathrm{~F}$ & 1.8 & 26.7 & 14 \\
\hline $82 \mathrm{M}$ & 1.5 & 28.3 & 9 \\
\hline Average & 1.68 & 24.0 & 13.8 or $53.3 \%$ \\
\hline
\end{tabular}

1.9 and those with ratios greater than 1.9 are compared; and for group 3 the cases with ratios less than 2.5 and those with ratios greater than 2.7 are compared. By eliminating the cases with lesion ratios of average magnitude in each group a fairly large difference in lesion ratios within each group is obtained.

The results of this analysis are presented in tables 9,10 and 11. Table 9 shows that for group 1 the rats with an average lesion ratio of 1.13 have an average lesion of 20.9 
per cent and make a score of 42.0 per cent correct, whereas the rats with an average lesion ratio of 1.68 have an average lesion of 24.0 per cent and make a score of 53.3 per cent correct. Despite a greater average lesion, the rats with the greater lesion ratio make the better score. In the case of group 2 (table 10) the rats with an average lesion ratio of

TABLE 10

Records of rats in group 2 with lesion ratios above and below the average

\begin{tabular}{|c|c|c|c|}
\hline RAT & $\begin{array}{c}\text { LESION } \\
\text { RATIO }\end{array}$ & $\begin{array}{c}\text { PER CENT } \\
\text { DESTRUDTION }\end{array}$ & $\begin{array}{l}\text { CORRECT } \\
\text { RUNS }\end{array}$ \\
\hline \multicolumn{4}{|c|}{ Cases with lesion ratios less than 1.9} \\
\hline $45 \mathrm{~F}$ & 1.8 & 9.0 & 14 \\
\hline $54 \mathrm{M}$ & 1.6 & 18.2 & 18 \\
\hline $53 \mathrm{M}$ & 1.6 & 21.3 & 16 \\
\hline $55 \mathrm{M}$ & 1.8 & 21.4 & 17 \\
\hline $62 \mathrm{~F}$ & 1.7 & 21.8 & 11 \\
\hline $68 \mathrm{~F}$ & 1.7 & 23.8 & 16 \\
\hline $52 \mathrm{M}$ & 1.8 & 23.9 & 17 \\
\hline $93 \mathrm{~F}$ & 1.4 & 26.1 & 8 \\
\hline $89 \mathrm{M}$ & 1.6 & 29.7 & 8 \\
\hline A verage & 1.67 & 21.7 & 13.9 or $54.3 \%$ \\
\hline \multicolumn{4}{|c|}{ Cases with lesion ratios greater than 1.9} \\
\hline $43 F$ & 2.3 & 15.4 & 18 \\
\hline $47 \mathrm{~F}$ & 2.2 & 17.6 & 17 \\
\hline $50 \mathrm{~F}$ & 2.0 & 21.1 & 18 \\
\hline $70 \mathrm{M}$ & 2.3 & 23.5 & 10 \\
\hline $41 \mathrm{~F}$ & 2.1 & 23.6 & 15 \\
\hline $40 \mathrm{~F}^{\prime}$ & 2.6 & 24.9 & 13 \\
\hline $48 \mathrm{~F}$ & 2.0 & 25.1 & 13 \\
\hline $44 \mathrm{~F}$ & 2.0 & 26.2 & 15 \\
\hline $42 \mathrm{~F}$ & 2.0 & 29.9 & 15 \\
\hline Average & 2.17 & 23.0 & 14.9 or $65.4 \%$ \\
\hline
\end{tabular}

1.67 have an average lesion of 21.7 per cent and make an average score of 54.3 per cent correct (similar to the score made by rats in group 1 with a similar lesion ratio), whereas the rats with an average lesion ratio of 2.17 have an average lesion of 23.0 per cent and make a score of 65.4 per cent correct. In group 3 (table 11) the rats with an average lesion ratio of 2.33 have an average lesion of 20.7 per cent and 
make a score of 66.7 per cent correct (which is similar to the score made by rats of group 2 with a similar lesion ratio), whereas the rats with a lesion ratio of 3.12 have an average lesion of 17.9 per cent and make a score of 83.3 per cent correct.

The points indicated by solid black circles in figure 2 graphically present these relationships between lesion ratios and the scores made. It will be seen that these points fall

TABLE 11

Records of rats in group 3 with lesion ratios above and below the average

\begin{tabular}{|c|c|c|c|}
\hline RAT & $\begin{array}{l}\text { LESION } \\
\text { RATIO }\end{array}$ & $\begin{array}{l}\text { PER OENT } \\
\text { DESTRUCTION }\end{array}$ & $\begin{array}{l}\text { CORRECT } \\
\text { RUNS }\end{array}$ \\
\hline \multicolumn{4}{|c|}{ Cases with lesion ratios less than 2.5} \\
\hline $30 \mathrm{M}$ & 2.2 & 16.1 & 15 \\
\hline $5 \mathbf{F}$ & 2.4 & 19.7 & 15 \\
\hline $22 \mathrm{M}$ & 2.4 & 20.3 & 17 \\
\hline $36 \mathrm{~F}$ & 2.3 & 21.4 & 15 \\
\hline $37 \mathrm{~F}$ & 2.3 & 21.5 & 17 \\
\hline $33 \mathrm{M}$ & 2.4 & 21.9 & 16 \\
\hline $23 \mathrm{M}$ & 2.3 & 23.9 & 10 \\
\hline Average & 2.33 & 20.7 & 15.0 or $66.7 \%$ \\
\hline \multicolumn{4}{|c|}{ Cases with lesion rations greater than 2.7} \\
\hline $31 \mathrm{M}$ & 3.5 & 10.5 & 17 \\
\hline $6 \mathrm{~F}$ & 3.1 & 14.9 & 16 \\
\hline $25 \mathrm{M}$ & 3.1 & 16.8 & 14 \\
\hline $24 \mathrm{M}$ & 2.8 & 17.7 & 17 \\
\hline $35 \mathrm{M}$ & 3.2 & 22.4 & 17 \\
\hline $2 \mathbf{F}$ & 3.0 & 25.2 & 18 \\
\hline Average & 3.12 & 17.9 & 16.5 or $83.3 \%$ \\
\hline
\end{tabular}

close to the straight line. When we consider that these averages of the lesion ratios and scores are based on very few cases and that the average lesions are not constant, this degree of consistency is rather striking.

Let us now consider some data obtained in a previous study (Maier, '32 c) treated in a similar manner. For the group of forty-eight rats the lesion ratio was found to be 1.23 , the average lesion 20.5 per cent, and the average score 43.5 per cent correct. Table 12 represents the records of, a) those 
TABLE 12

Records of rats in previous investigation (Maier, $39 c$ ) with lesions above and below the average

\begin{tabular}{|c|c|c|c|c|}
\hline $\mathbf{R A T}$ & $\underset{\text { RATIO }}{\text { LESION }}$ & $\begin{array}{l}\text { PER CENT } \\
\text { DESTRUCTION }\end{array}$ & $\begin{array}{l}\text { CORLECT } \\
\text { RUNS }\end{array}$ & $\begin{array}{l}\text { INCORREOT } \\
\text { RUNS }\end{array}$ \\
\hline \multicolumn{5}{|c|}{ Cases with lesion ratios less than 1.2} \\
\hline 3 & 1.0 & 10.4 & 11 & 4 \\
\hline 10 & 1.1 & $14 . \overline{5}$ & 13 & 2 \\
\hline 11 & 1.0 & 16.8 & 12 & 3 \\
\hline 12 & 1.0 & 17.7 & 11 & 4 \\
\hline 13 & 1.1 & 18.1 & 13 & 2 \\
\hline 14 & 1.1 & 18.3 & 15 & 0 \\
\hline 15 & 1.0 & 18.5 & 12 & 3 \\
\hline 16 & 1.0 & 18.5 & 13 & 2 \\
\hline 17 & 1.0 & 18.9 & 13 & 2 \\
\hline 21 & 1.0 & 20.8 & 13 & 2 \\
\hline 23 & 1.0 & 21.3 & 13 & 2 \\
\hline 29 & 1.0 & 22.3 & 13 & 2 \\
\hline 30 & 1.0 & 22.3 & 4 & 11 \\
\hline 33 & 1.0 & 23.0 & 8 & 7 \\
\hline 35 & 1.1 & 23.4 & 9 & 6 \\
\hline 36 & 1.1 & 23.4 & 8 & 7 \\
\hline 37 & 1.0 & 24.0 & 6 & 9 \\
\hline 39 & 1.0 & 24.5 & 6 & 9 \\
\hline 41 & 1.1 & 25.1 & 9 & 6 \\
\hline 44 & 1.1 & 25.8 & 9 & 6 \\
\hline 45 & 1.0 & 26.2 & 8 & 7 \\
\hline 46 & 1.1 & 30.9 & 6 & 9 \\
\hline Average & 1.04 & 21.1 & 10.2 & 4.8 or $36.3 \%$ correct \\
\hline \multicolumn{5}{|c|}{ Cases with lesion ratios greater than 1.3} \\
\hline 1 & 1.4 & 9.8 & 15 & 0 \\
\hline 2 & 1.5 & 9.8 & 15 & 0 \\
\hline 4 & 1.6 & 10.8 & 12 & 3 \\
\hline 8 & 1.4 & 13.2 & 10 & 5 \\
\hline 9 & 1.5 & 14.0 & 15 & 0 \\
\hline 18 & 1.5 & 19.1 & 15 & 0 \\
\hline 19 & 1.5 & 20.0 & 12 & 3 \\
\hline 26 & 1.5 & 21.9 & 8 & 7 \\
\hline 28 & 1.4 & 22.1 & 14 & 1 \\
\hline 34 & 1.7 & 23.4 & 7 & 8 \\
\hline 42 & 1.5 & 25.2 & 8 & 7 \\
\hline 47 & 1.8 & 31.5 & 9 & 6 \\
\hline 48 & 1.5 & 37.2 & 8 & 7 \\
\hline Average & 1.52 & 19.9 & 11.4 & 3.6 or $51.8 \%$ correct \\
\hline
\end{tabular}

For group of forty-eight rats the average lesion, lesion ratio and score were 20.5 per cent, 1.23 and 43.5 per cent, respectively. Fifteen instead of eighteen test runs were given. 
cases with lesion ratios less than 1.2 ; and, b) those with lesion ratios greater than 1.3. From this table it will be seen that the rats with lesion ratios less than average have an average lesion ratio of 1.04, an average lesion of 21.1 per cent, and make a score of 36.3 per cent correct; whereas those rats with lesion ratios greater than the average have an average lesion ratio of 1.52, an average lesion of 19.9 per cent, and make a score of 51.8 per cent correct. In figure 2 these lesion ratios plotted against the scores are represented by circled crosses. Again we find that with the average lesion remaining about the same the plotted points fall close to the straight line.

From these results it seems safe to conclude that the ratio of the length to the width of a lesion is an important aspect of a cortical lesion. This study does not include cases in which the width of a lesion is greater than its length. We cannot, therefore, state whether these results indicate that it is the perimeter of a lesion which is basic in our results or whether it is purely the relative length of a lesion which is important. Theorizing on the basis of mass action, these results indicate that deterioration is a function of the concentration of a lesion. If this is true, it follows that it is the perimeter of lesion which determined the difference in the effectiveness of our lesions. On the other hand, if we consider the fact that most association fibers run along the long axis of the brain and that, because of this, long lesions are consequently less destructive, then it follows that the relative length of a lesion is important. ${ }^{2}$

I have previously shown that the destruction of sensory projection areas cannot account for the low scores made by operated rats (Maier, '32 b, '32 c). One can therefore not successfully explain these results by pointing to a difference in number of sensory areas which elongated and round lesions may invade.

${ }^{2}$ This possibility was suggested by Dr. Elizabeth Crosby. 


\section{SLMMARY}

Three groups of rats were subjected to cortical injuries as follows: 1) in the first group, tissue was destroyed through one pair of trephine openings; 2) in the second group, through two pairs of trephine openings; and, 3) in the third group through three pairs of trephine openings. Histological examinations revealed that the amount of tissue destroyed was similar and that the cortical areas covered were the same.

All groups were tested before and after operation for reasoning ability. It was found that the post-operative scores for the three groups were decidedly unlike, being highest for group 3 and lowest for group 1. The data were analyzed to determine the cause of these differences in score. Analysis revealed that when the amount of cortical destruction was constant, there was a difference in deterioration in reasoning ability which was inversely proportional to the ratio of the length to the width of the lesions.

It is concluded that the pattern of a lesion as well as its mass is an important factor determining the degree of resulting deterioration. Possible theoretical consequences of these findings are suggested.

\section{LITERATURE CITED}

LASHLEY, K. S. 1929 Brain mechanisms and intelligence. Univ. Chicago Press. 1933 Integrative functions of the cerebral cortex. Physiol. Rev., vol. 13, pp. 1-42.

LAsHLEY, K. S., AND L. E. WILET 1933 Studies of cerebral function in learning. IX. Mass action in relation to the number of elements in the problem to be learned. J. Comp. Neur., vol. 57, pp. 3-55.

MaIkR, N. R. F. 1929 Reasoning in white rats. Comp. Psyehol. Mono., vol. 6, pp. 1-93.

1930 Attention and inattention in rats. J. Genet. Psychol, vol. 38 , pp. $288-306$.

1931 Reasoning and learning. Psychol. Rev., vol. 38, pp. 332-346. 1932 a Age and intelligence in rats. J. Comp. Psycho!., vol. 13, pp. 1-6.

$1932 \mathrm{~b}$ The effect of cerebral destruetion on reasoning and learning in rats. J. Comp. Neur., vol. 54, pp. 45-75.

$1932 \mathrm{e}$ Cortical destruetion in the posterior part of the brain and its effect on reasoning in rats. J. Comp. Neur., rol. 56, pp. 179-214. 
PLATES 1, 2 AND 3

The following plates diagrammatically represent the extent and locus of the lesions suffered by rats in groups 1,2 and 3 . The black portions represent the symmetrical parts of the lesions, the stippled portions the asymmetrical parts. Only the dorsal aspects of the brains are shown, because the lesions invaded the lateral aspects in but a small number of eases and in these the amount of invasion was slight.

The extent of invasion of the lateral portions which are not visible in our diagrams was as follows:

\begin{tabular}{cc}
\multicolumn{2}{c}{ Group 1} \\
Rat & $\begin{array}{c}\text { Extent of lesion not } \\
\text { shown in diagram } \\
\text { Per cent }\end{array}$ \\
$66 \mathrm{~F}$ & 0.9 \\
$88 \mathrm{M}$ & 0.6 \\
$64 \mathrm{~F}$ & 0.5 \\
$96 \mathrm{~F}$ & 0.5 \\
$83 \mathrm{M}$ & 1.3 \\
$94 \mathrm{~F}$ & 1.7 \\
$91 \mathrm{~F}$ & 1.0 \\
$82 \mathrm{M}$ & 1.0 \\
$86 \mathrm{M}$ & 0.6
\end{tabular}

$\begin{array}{cc}\text { Group \& } \\ \text { Rat } & \begin{array}{c}\text { Extent of lesion not } \\ \text { shown in diagram } \\ \text { Per cent }\end{array} \\ 50 \mathrm{~F} & 0.2 \\ 93 \mathrm{~F} & 0.4 \\ 89 \mathrm{M} & 0.3 \\ 81 \mathrm{M} & 0.1 \\ \text { Group } S & \\ \text { No cases } & \end{array}$




\section{GROUP।}
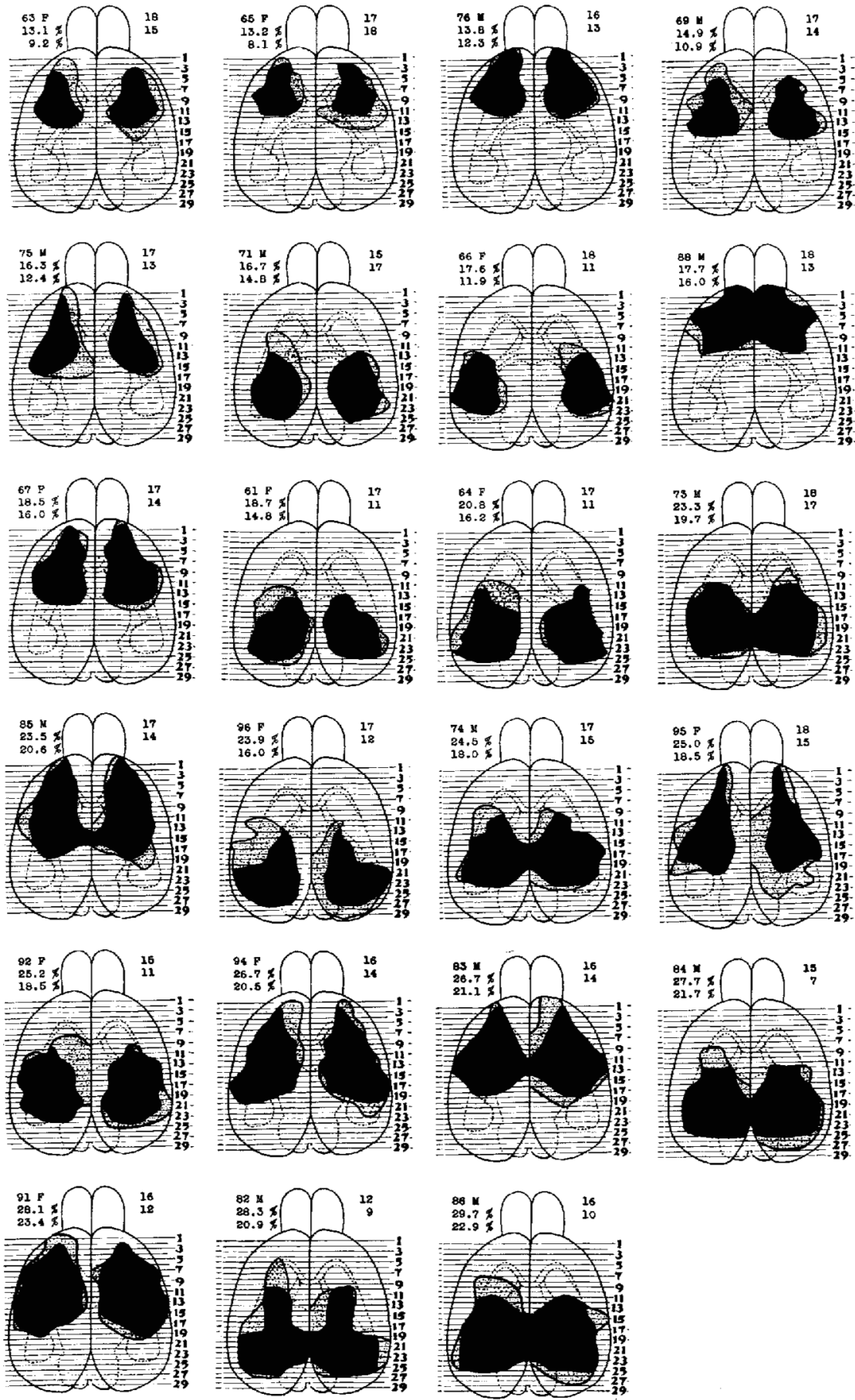


\section{GROUP 2}
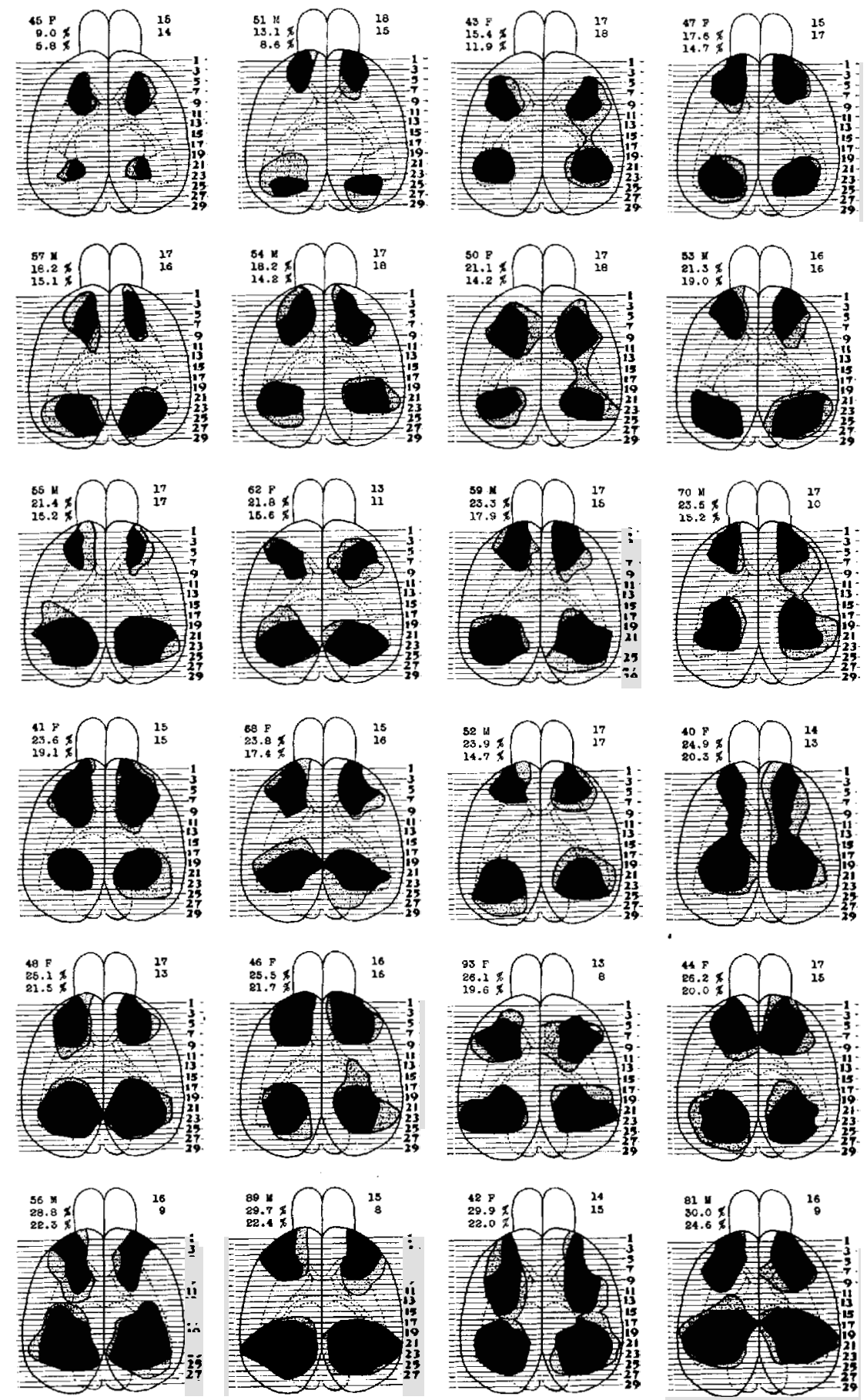


\section{Geoup 3}
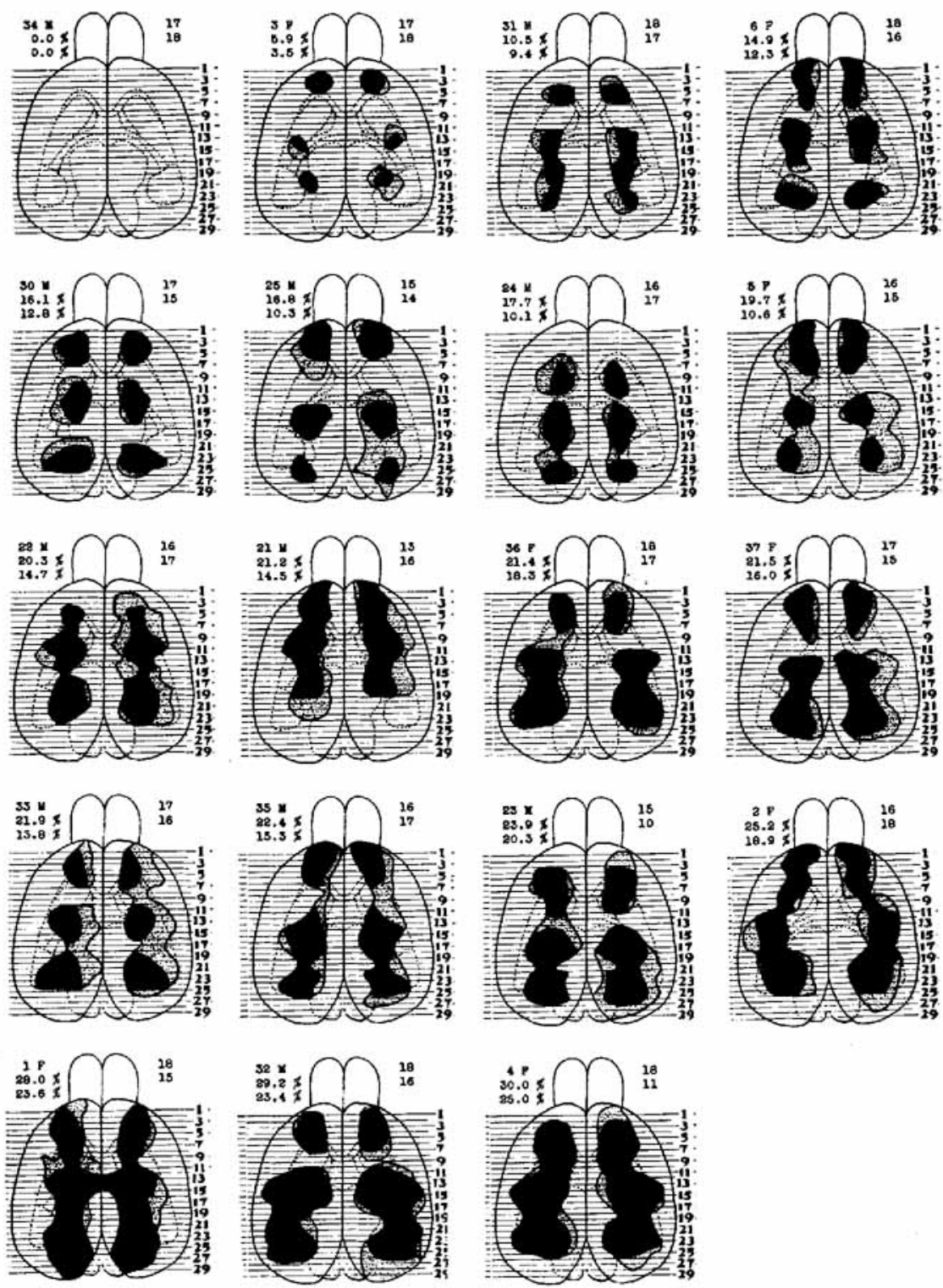